\title{
Hypoxia Inhibits Proliferation of Fetal Pulmonary Arterial Smooth Muscle Cells in Vitro
}

\author{
WILLIAM E. BENITZ, JOHN D. COULSON, DANIEL S. LESSLER, AND MERTON BERNFIELD \\ Divisions of Neonatology and Developmental Biology, Department of Pediatrics, Stanford University School of \\ Medicine, Stanford, California 94305
}

\begin{abstract}
Normal pulmonary arterial development in the relatively hypoxic intrauterine environment and pulmonary arterial remodeling in hypoxic infants include extension of the smooth muscle layer into normally nonmuscular arteries and thickening of the arterial media in the muscular arteries. These changes require proliferation of immature smooth muscle cells or differentiation of smooth muscle cell precursors. Because the mechanisms that regulate these processes have not been clearly defined, we asked whether decreased oxygen tensions could promote either hyperplasia or hypertrophy of smooth muscle cell precursors in vitro. We have studied cells that proliferate and migrate out of explants from the media of the pulmonary arteries of near-term bovine fetuses, because these cells are representative of those that are involved in normal arterial development and possibly also in arterial remodeling. Decreases in oxygen tension within and below the physiologic range do not cause hyperplasia or hypertrophy of these cells. Instead, cell proliferation decreased at oxygen tensions below $60 \mathrm{~mm} \mathrm{Hg}$. The effects of hypoxia on proliferation of aortic and pulmonary arterial smooth muscle cells were identical, but effects on proliferation of dermal fibroblasts and endothelial cells were smaller in magnitude and evident only at lower oxygen tensions. These findings suggest that hypoxia does not act directly on smooth muscle cells to produce increased quantities of these cells in the pulmonary arteries during normal prenatal development or during remodeling of the pulmonary arteries of the hypoxic neonate, implying that other factors mediate these phenomena. (Pediatr Res 20: 966-972, 1986)
\end{abstract}

\section{Abbreviations}

DMEM, Dulbecco's modified Eagle medium FBS, fetal bovine serum SMC, smooth muscle cells

Hypoxia is associated with pulmonary hypertension and pulmonary arterial remodeling in newborn animals (1-4) and hu-

Received February 20, 1986; accepted May 20, 1986.

Address for correspondence and reprint requests William E. Benitz, M.D. Department of Pediatrics-Room S222, Stanford University School of Medicine, Stanford, CA 94305.

Supported by Grant HD06763 from the National Institutes of Health. W.E.B. is a recipient of a Clinician-Scientist Award from the American Heart Association, with funds contributed in part by the California Affiliate. J.D.C. was supported by the United States Navy. D.S.L. was supported by a Medical Student Traineeship of the Cystic Fibrosis Foundation and by the Stanford Medical Alumni Medical Scholars Program. man infants (5-7). The proximal muscular arteries are remodeled by thickening of the tunica media, which may be caused by hypertrophy of medial smooth muscle cells (6), increased abundance of extracellular matrix (3), proliferation of SMC, and/or differentiation of their precursors (1). The peripheral nonmuscular and partially muscular arteries are remodeled by appearance of new smooth muscle in those vessels $(1,2,4)$, a process that requires proliferation of SMC or their precursors. Proliferation and peripheral extension of the SMC in the media of the pulmonary arteries is also prominent in normal prenatal development $(8,9)$, and it has been suggested that the relative hypoxia of the intrauterine environment may be an important stimulus for this process (9).

The mechanisms that regulate proliferation and differentiation of SMC or their precursors in the fetus and newborn are unknown. Proliferation could be accelerated by hypoxia itself, as has been reported for fibroblasts $(10,11)$, chondrocytes (12), and embryonic myocardial cells (13). We have examined the effects of oxygen tension on proliferation of SMC cultured from the pulmonary arteries of near-term bovine fetuses. At oxygen tensions within and below the physiologic range, lower oxygen tensions were associated with reduced proliferation of these cells, and cellular hypertrophy was not observed. These results suggest that although low oxygen tension may be a necessary stimulus, the direct effects of oxygen tension on SMC are not sufficient to account for the increasing quantity of smooth muscle in the pulmonary arteries during normal prenatal development and in association with hypoxemia.

\section{METHODS}

Cell culture. SMC from near-term fetal, newborn, and adult bovine pulmonary artery and fetal bovine aorta were cultured by an adaptation of the explant technique (14) and characterized as described previously (15). By electron microscopy, these cells had the clusters of plasmalemmal vesicles and bundles of thin $(5-8 \mathrm{~nm})$ filaments with associated dense bodies that characterize SMC $(16,17)$. Filamentous bundles occupied less than $50 \%$ of the cytoplasm and were predominantly distributed near the side of the cell adjacent to the culture dish. The remainder of the cytoplasm was filled with free ribosomes, rough endoplasmic reticulum, and mitochondria. These features are typical of vascular SMC in the "synthetic" phenotype (16).

Pulmonary arterial endothelial cells were cultured by gently scraping the endothelium off of the intimal surface of vessels obtained from near-term bovine fetuses and plating in serumsupplemented medium (18). These endothelial cell cultures became confluent after 5 to 7 days and were selected by treatment with ${ }^{3} \mathrm{H}$-thymidine, as described by Schwartz (19). These cells exhibited typical cobblestone morphology by phase microscopy (20) and stained specifically with acetylated low density lipopro- 
tein (21; provided by Dr. Robert Auerbach, University of Wisconsin) and with antibodies to Factor VIII (Accurate Chemical, Hicksville, NY) (20).

Dermal fibroblasts were grown from fetal bovine skin using standard methods (22). Cells were released from culture vessels by trypsin treatment and passaged as described previously (15). All experiments used cells in the third passage after harvest from the primary culture. Experimental results did not differ for cells harvested on different occasions. Stocks were maintained in DMEM (GIBCO, Grand Island, NY) supplemented with penicillin $(10 \mathrm{U} / \mathrm{ml})$, streptomycin $(10 \mu \mathrm{g} / \mathrm{ml})$, and $10 \%$ FBS (Tissue Culture Biologicals, Tulare, CA). Experimental cultures were grown in the same medium unless otherwise specified. All cultures were incubated at $37^{\circ} \mathrm{C}$ in a humidified atmosphere of $5 \%$ $\mathrm{CO}_{2}$.

Regulation of ambient gas tensions. Chambers in which cell cultures could be incubated under a variety of ambient oxygen tensions were prepared by equipping plastic laboratory dessicators (Fisher Scientific, Pittsburgh, PA) with nipple fittings, providing an outlet to allow flushing the dessicator with gas mixtures. Achievement of positive pressure $\left(15\right.$ to $\left.30 \mathrm{~cm} \mathrm{H}_{2} \mathrm{O}\right)$ inside the dessicator was made possible by clamping the top of the dessicator to its base at its perimeter with binder clamps and attachment of the outflow tubing to an underwater seal. Positive pressure was maintained by closing both the inlet and outlet of each chamber, and was monitored with a water manometer. Humidity was maintained by placement of an open 10-cm Petri dish filled with distilled water in each chamber.

Standard gas mixtures, consisting of air with $5 \% \mathrm{CO}_{2}$ or nitrogen with $5 \% \mathrm{CO}_{2}$, were blended in various proportions (using dual flowmeters with needle valve controls; Cole-Parmer, Chicago, IL) so that the chambers could be flushed with gas at selected oxygen tensions between 0 and $145 \mathrm{~mm} \mathrm{Hg}$. Each chamber was flushed with four times its volume of gas, so that the final gas tensions were theoretically $98 \%$ equilibrated with those of the flushing gas mixture. Gas samples were drawn into glass syringes (which were filled and emptied three times before the final sample was collected) by puncture of self-resealing rubber tubing, and oxygen and carbon dioxide tensions were measured using a blood gas analyzer (model 178, Corning, Medfield, MA). Gas tensions were reproducible and stable to within $\pm 3 \mathrm{~mm} \mathrm{Hg}$ ). All chambers were flushed every $48 \mathrm{~h}$ during each experiment.

Measurement of gas tensions in the medium demonstrated complete equilibration with the gas in each chamber within $1 \mathrm{~h}$ after flushing of the chambers. Because the volume of gas in each chamber was large relative to the volume of medium (more than 100 -fold), equilibration with the medium had no detectable effect on partial pressures of oxygen or carbon dioxide in the gas phase.

Cell proliferation. Cells harvested from confluent cultures by trypsin treatment were replated into $35-\mathrm{mm}$ tissue culture dishes (Becton Dickenson, Oxnard, CA) at an initial density of $2.5 \times$ $10^{3}$ cells $/ \mathrm{cm}^{2}$ and placed in humidified chambers under various ambient oxygen tensions. At that time (day 0) and at intervals of 1 to 2 days thereafter, triplicate dishes for each condition were collected, rinsed, filled with $\mathrm{NaCl}(2 \mathrm{M})$-phosphate $(50 \mathrm{mM})$ EDTA $(2 \mathrm{mM})$ buffer ( $\mathrm{pH} 7.4)$, and frozen at $-20^{\circ} \mathrm{C}$. When all samples had been collected, they were thawed, sonicated, and aliquots were taken for DNA assay by the bisbenzimidazole (Hoechst 33258, American Hoechst Corp., Sommerville, NJ) spectrofluorimetric method (23), using calf thymus DNA (Sigma, St. Louis, MO) standards, as described previously (15). All samples for each experiment were assayed simultaneously using a single DNA standard solution. Standardization studies confirmed that the DNA content was directly proportional to the number of cells in each sample.

The protein content of the cell sonicate was determined by a modification of the Serva Blue G (Accurate Chemical, Hicksville, NY) spectrophotometric dye-binding method (24). Each 700- $\mu$ l aliquot was added to $300 \mu$ l of Serva Blue G $(0.02 \%)$ in phos- phoric acid (4 M)-ethanol (2 M). Bovine serum albumin in $\mathrm{NaCl}$ phosphate-EDTA buffer was used as a reference standard. The absorbance of each sample, relative to a reagent blank, was determined at $595 \mathrm{~nm}$. The protein content of unknown samples was determined by interpolation of relative absorbance values on the curvilinear standard curve, allowing assay of samples with protein contents ranging from 2 to $60 \mu \mathrm{g} / \mathrm{ml}$. Samples containing more than $60 \mu \mathrm{g} / \mathrm{ml}$ were diluted $1: 5$ before assay.

Statistical analysis (25). The DNA or protein content of each sample is expressed as the mean \pm SD for at least three dishes. In Figures 1 to 6, all error bars which are smaller than the symbols used to indicate mean values are omitted. The DNA or protein contents were initially compared by two-way analysis of variance and significant differences were further identified using one-way analysis of variance. Selected pairs of sample means were compared using Student's unpaired two-tailed $t$ test. The Bonferroni correction was applied whenever such $t$ tests were utilized iin multiple comparisons. Significance was assumed at $p$ $<0.05$.

\section{RESULTS}

Effects of oxygen tension on cell proliferation. Other reports (26-28) have suggested that proliferation of adult aortic SMC is more rapid in $5 \%$ than in $20 \%$ oxygen $\left(\mathrm{Po}_{2} 38\right.$ versus $150 \mathrm{~mm}$ $\mathrm{Hg}$ ). We also found that proliferation of smooth muscle cells from adult bovine pulmonary arteries (as reflected in the DNA content of cultures after 10 days) was slower at oxygen tensions greater than $100 \mathrm{~mm} \mathrm{Hg}$ than at 50 to $90 \mathrm{~mm} \mathrm{Hg}(p<0.01)$. No decrement in proliferation of cells from fetal or newborn bovine pulmonary arteries was apparent (Fig. 1). However, proliferation of SMC from each of these sources was progressively reduced as the oxygen tension was reduced below $50 \mathrm{~mm} \mathrm{Hg}(p$ $<0.0005$ ).

To better characterize the effects of oxygen tensions below 100 $\mathrm{mm} \mathrm{Hg}$, cultures of fetal SMC grown at oxygen tensions ranging from 2 to $97 \mathrm{~mm} \mathrm{Hg}$ (allowing $\mathrm{PO}_{2}$ increments of 20 rather than $30 \mathrm{~mm} \mathrm{Hg}$ ) were sampled at 2-day intervals. The rate of proliferation and the cell density achieved after 8 days were both reduced in cultures maintained at oxygen tensions below $50 \mathrm{~mm}$ $\mathrm{Hg}(p<0.0005)$, and the greatest reductions were observed at

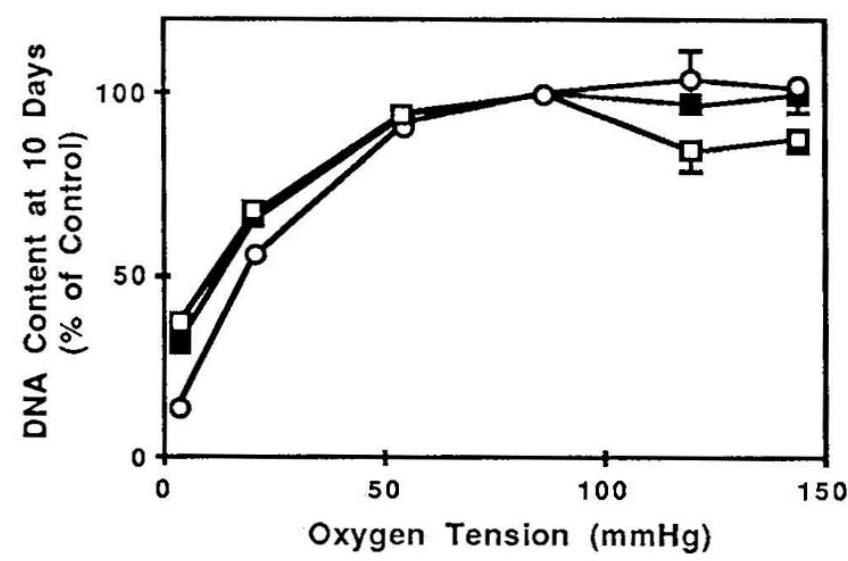

Fig. 1. Comparison of fetal, newborn, and adult SMC growth. SMC from adult $(\square)$, newborn $(\mathbf{\square})$, and fetal $(\mathrm{O})$ bovine pulmonary arteries plated in DMEM with $20 \%$ FBS at $2.5 \times 10^{3}$ cells per $\mathrm{cm}^{2}$ in $35-\mathrm{mm}$ dishes were incubated under ambient oxygen tensions ranging from 2 to $145 \mathrm{~mm} \mathrm{Hg}$. Proliferation of adult pulmonary arterial SMC was reduced at oxygen tensions greater than $100 \mathrm{~mm} \mathrm{Hg}(p<0.01)$, but no growth decrement at higher oxygen tensions was apparent for either fetal or newborn calf pulmonary arterial SMC. Growth of cells from animals of all three ages was significantly reduced at oxygen tensions below $50 \mathrm{~mm}$ $\mathrm{Hg}(p<0.0005)$. Cultures incubated at $83 \mathrm{~mm} \mathrm{Hg}$ were arbitrarily designated as controls for this experiment. 
the lowest oxygen tensions (Fig. 2). Proliferation ceased after 6 days in cultures incubated at oxygen tensions below $50 \mathrm{~mm} \mathrm{Hg}$, but continued for 8 days in cultures exposed to higher oxygen tensions. Changes in the protein content of these cultures were closely proportionate to changes in the DNA content at all oxygen tensions, indicating that cellular hypertrophy did not occur in response to altered oxygen tensions.

Cultured SMC maintained normal cellular morphology, without detachment, rounding, or vacuole formation, except in cultures maintained at extremely low oxygen tension $(2 \mathrm{~mm} \mathrm{Hg})$ for 8 days, when many cells appeared spindly and pyknotic (Fig. $3)$. In addition, the rate of cell proliferation was restored to control values when cultures were transferred to higher oxygen tensions $(83.6 \pm 0.8 \mathrm{~mm} \mathrm{Hg})$ after 5 days at low oxygen tension (10.4 $\pm 0.6 \mathrm{~mm} \mathrm{Hg}$; see Fig. 4). Although these "recovery" cultures continued to proliferate for 8 days, as did the control (i.e. high $\mathrm{PO}_{2}$ ) cultures, they reached a cell density at 10 days which was only $80 \%$ of that in cultures continuously exposed to higher oxygen tensions.

Comparison with other cell types. Because the aortic and pulmonary arterial oxygen tensions differ $(20-25$ versus $25-30$ $\mathrm{mm} \mathrm{Hg}$, respectively, in the fetus and 70-90 versus $40-45 \mathrm{~mm}$ $\mathrm{Hg}$ in the adult), one might hypothesize that cells from these vessels might exhibit differential responses to hypoxia. However, the effects of variation of ambient oxygen tension on proliferation of smooth muscle cells from the fetal aorta and pulmonary artery, as assessed by measurement of the DNA content of culture dishes after 8 days in culture, were identical (Fig. 5). In this experiment, there was virtually no proliferation of SMC incubated at the lowest oxygen tensions $(1.4 \pm 0.9 \mathrm{~mm} \mathrm{Hg})$; in several such experiments, SMC grown at oxygen tensions less than 3 $\mathrm{mm} \mathrm{Hg}$ never exceeded three doublings.

In contrast to the effects observed with SMC, proliferation of skin fibroblasts was only modestly reduced at oxygen tensions between 20 and $50 \mathrm{~mm} \mathrm{Hg}$, and after 8 days at very low oxygen tension $(1.4 \pm 0.9 \mathrm{~mm} \mathrm{Hg})$ these cells had completed nearly five doublings, achieving a density that was $28 \%$ of that in control cultures (Fig. 5). Pulmonary arterial endothelial cells were similarly tolerant of low oxygen tensions (data not shown). Thus, the effects of oxygen tension on proliferation of arterial SMC were specific properties of these cells, rather than simply a generic property of fetal bovine cells in culture.

Effects of other culture conditions on cellular response to hypoxia. Because culture conditions can alter the in vitro cellular responses to many effectors, we analyzed whether changes in culture conditions altered the effect of hypoxia on proliferation of fetal pulmonary arterial SMC. Plating the cells at an initial density at which the cells were contiguous $\left(20 \times 10^{3}\right.$ rather than $2.5 \times 10^{3}$ cells $/ \mathrm{cm}^{2}$ ) did not alter the relative effects of different oxygen tensions on cell proliferation (Fig. $6 A$ ). Reducing the concentration of FBS in the culture medium decreased the rate of proliferation, thus limiting the maximum density achieved at any oxygen tension and reducing the threshhold oxygen tension below which slower cell proliferation became apparent (Fig. $6 B$ ). An optimal range of oxygen tension was not evident in DMEM supplemented with 5, 10, or $20 \%$ FBS (Fig. $6 B$ ). In medium consisting of equal parts DMEM and F12 medium with $20 \%$ FBS, however, proliferation of fetal pulmonary arterial SMC was greatest at an oxygen tension of $83 \mathrm{~mm} \mathrm{Hg}$; cell densities achieved after 10 days were lower in cultures maintained at higher $(p<$ $0.001)$ or lower $(p<0.0005)$ oxygen tensions (Fig. $6 C)$. Use of serum prepared from fetal bovine plasma, in which plateletderived growth factor is not detectable (15), rather than FBS, did not alter these results (data not shown). These results indicate that although variation in culture conditions does affect cell growth, proliferation of SMC under each of these various conditions was consistently and progressively reduced at oxygen tensions below $50 \mathrm{~mm} \mathrm{Hg}$.

\section{DISCUSSION}

Proliferation of SMC or their precursors is a prominent feature of both normal in utero development $(8,9)$ and hypoxic remodeling (2-7) of the pulmonary arteries, but the mechanisms that regulate this process have not been clearly defined. To determine whether direct effects of hypoxia on immature or precursor SMC could account for the increased quantity of smooth muscle found in the pulmonary arteries of hypoxic young animals $(2,3)$ and infants (5-7), we studied cells cultured from explants from the
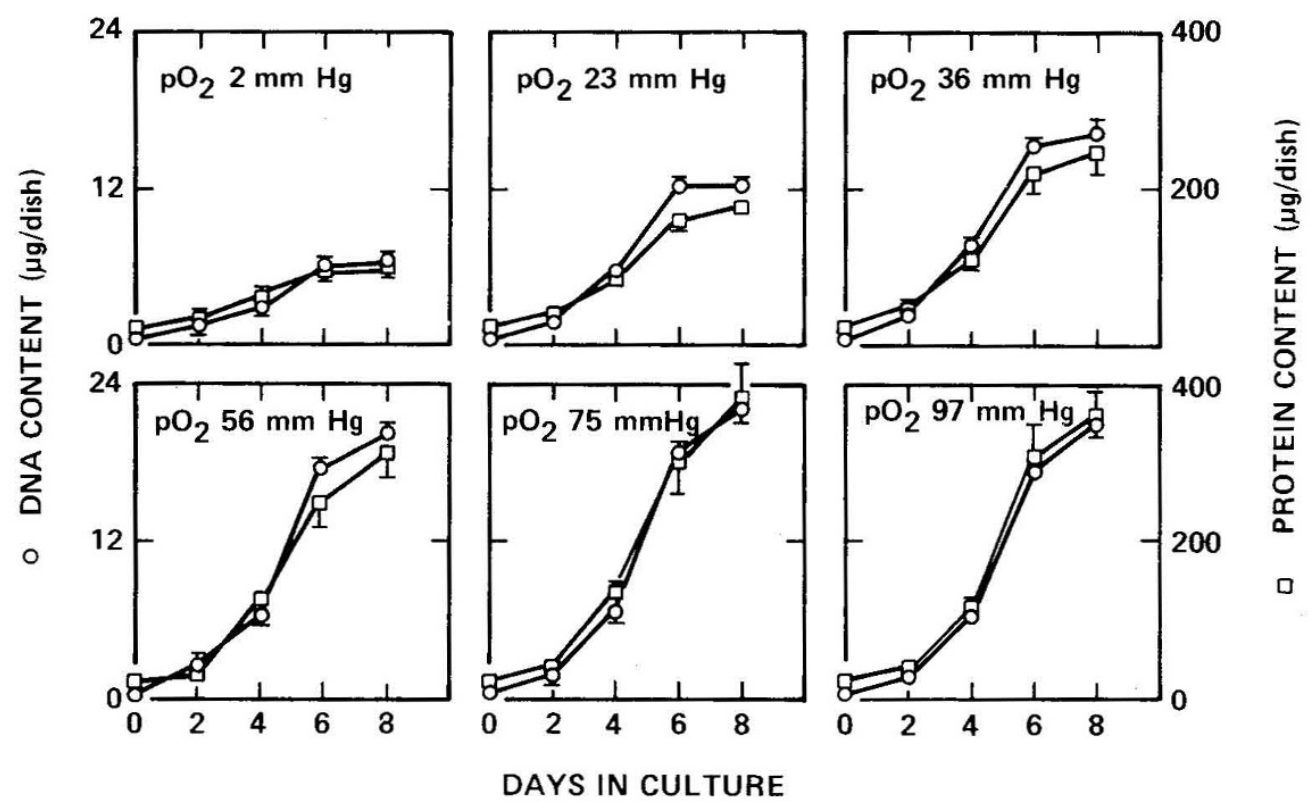

Fig. 2. Growth of SMC at different ambient oxygen tensions. Fetal pulmonary arterial SMC plated in DMEM with $10 \%$ FBS at $2.5 \times 10^{3}$ cells per $\mathrm{cm}^{2}$ in $35-\mathrm{mm}$ dishes were incubated under ambient oxygen tensions ranging from 2 to $97 \mathrm{~mm} \mathrm{Hg}$. Cell proliferation was slower and cell densities after 8 days in culture were lower in cultures exposed to ambient oxygen tensions less than $60 \mathrm{~mm} \mathrm{Hg}$. Changes in the cellular protein content $(\square)$ were closely proportionate to the DNA content $(O)$ of these cultures, indicating that cellular hypertrophy did not occur. Reduction in the DNA content of culture dishes at all oxygen tensions below $50 \mathrm{~mm} \mathrm{Hg}$ was significant $(p<0.0005)$ for days 4,6 , and 8 . 


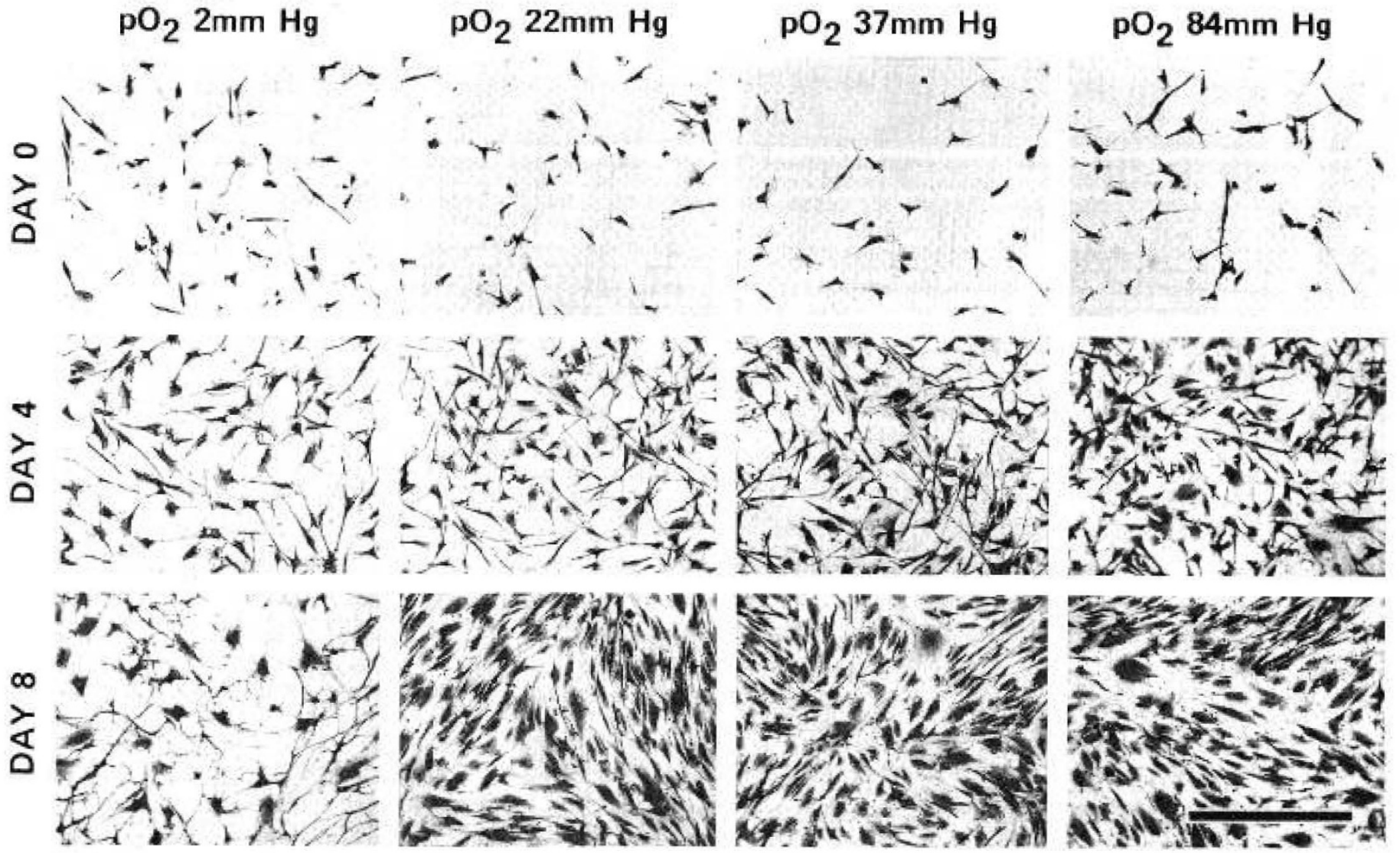

Fig. 3. SMC growth at different ambient oxygen tensions. Fetal pulmonary arterial SMC plated as in Figure 2 were incubated under ambient oxygen tensions ranging from 2 to $84 \mathrm{~mm} \mathrm{Hg}$. Cultured cells were fixed on the culture dish with $1.8 \%$ formalin and stained with toluidine blue. Normal cellular morphology was maintained under all experimental conditions except for extreme hypoxia $\left(\mathrm{PO}_{2}\right.$ of $\left.2 \mathrm{~mm} \mathrm{Hg}\right)$ for 8 days. Because these fields were chosen primarily to demonstrate cell morphology, they do not precisely reflect the cell densities of these cultures. Bar represents $500 \mu \mathrm{m}$.

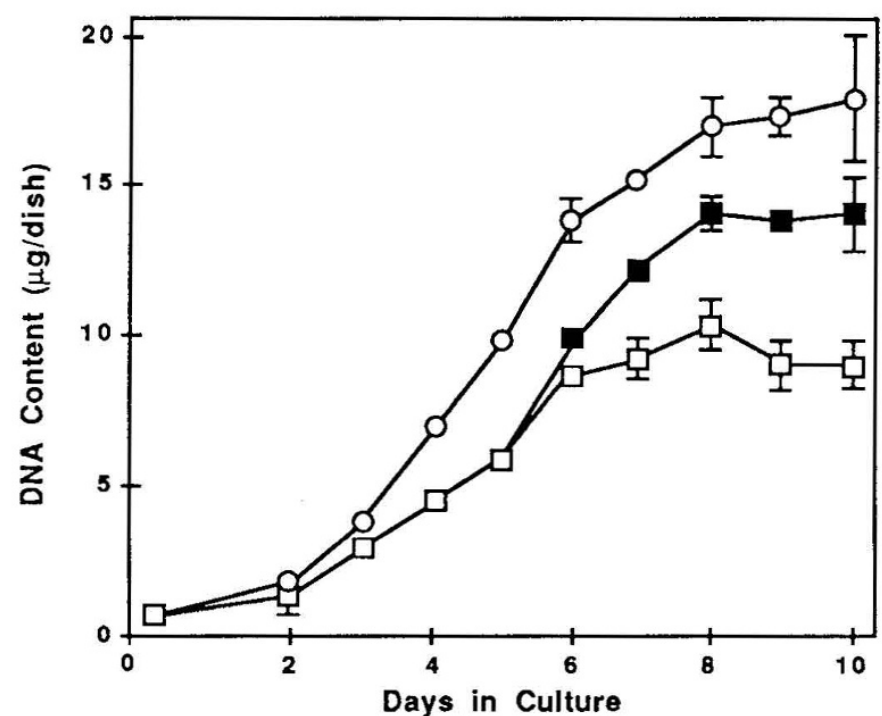

Fig. 4. Recovery of SMC proliferation after hypoxia. SMC from fetal bovine pulmonary arteries were cultured as in Figure 2 at ambient oxygen tensions of $84 \pm 1 \mathrm{~mm} \mathrm{Hg}(O)$ or $10 \pm 1 \mathrm{~mm} \mathrm{Hg}(\square)$ for 10 days, or at $10 \mathrm{~mm} \mathrm{Hg}$ for 5 days followed by 5 days at $84 \mathrm{~mm} \mathrm{Hg} \mathrm{( \square ).} \mathrm{SMC}$ proliferated more slowly and reached a lower cell density at 10 days when incubated at low oxygen tensions $(p<0.0005)$, but the rate of proliferation recovered when the cultures were returned to higher oxygen tensions after 5 days at low oxygen tension.

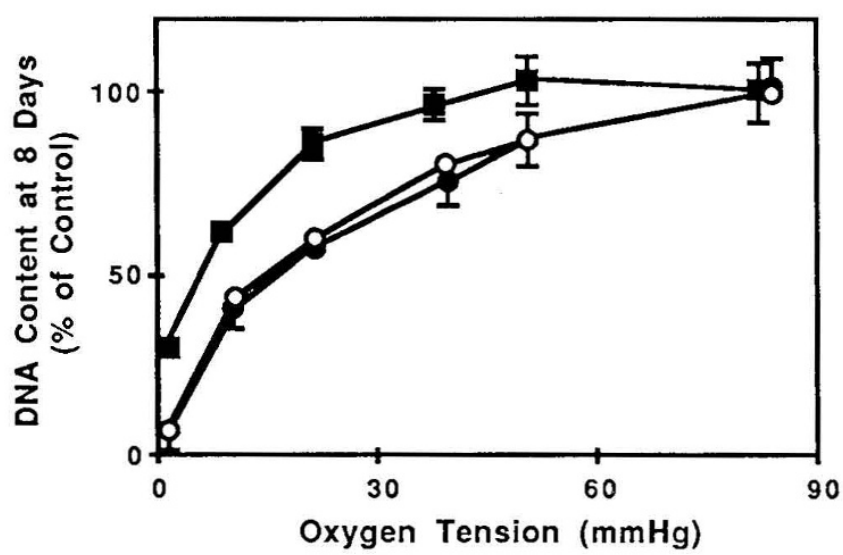

Fig. 5. Growth of SMC and fibroblasts at different oxygen tensions. Fetal bovine SMC and skin fibroblasts were cultured as in Figure 2. Proliferation of SMC from pulmonary artery $(O)$ or aorta $(\bullet)$, as reflected by the DNA content of culture dishes after 10 days in culture, was inhibited at oxygen tensions below $60 \mathrm{~mm} \mathrm{Hg}$. The effects of oxygen tension on proliferation of pulmonary arterial and aortic SMC were identical. Inhibition of proliferation of fetal bovine skin fibroblasts ( $\square$ ) was apparent only at oxygen tensions below $40 \mathrm{~mm} \mathrm{Hg}$, and was smaller in magnitude than that observed for SMC at comparable oxygen tensions. Differences between SMC and fibroblasts were significant $(p<0.005)$ at all oxygen tensions less than $50 \mathrm{~mm} \mathrm{Hg}$. The DNA contents of all samples are expressed as percentages of the content of control cultures (those incubated at $83 \mathrm{~mm} \mathrm{Hg}$ ) at 8 days. 

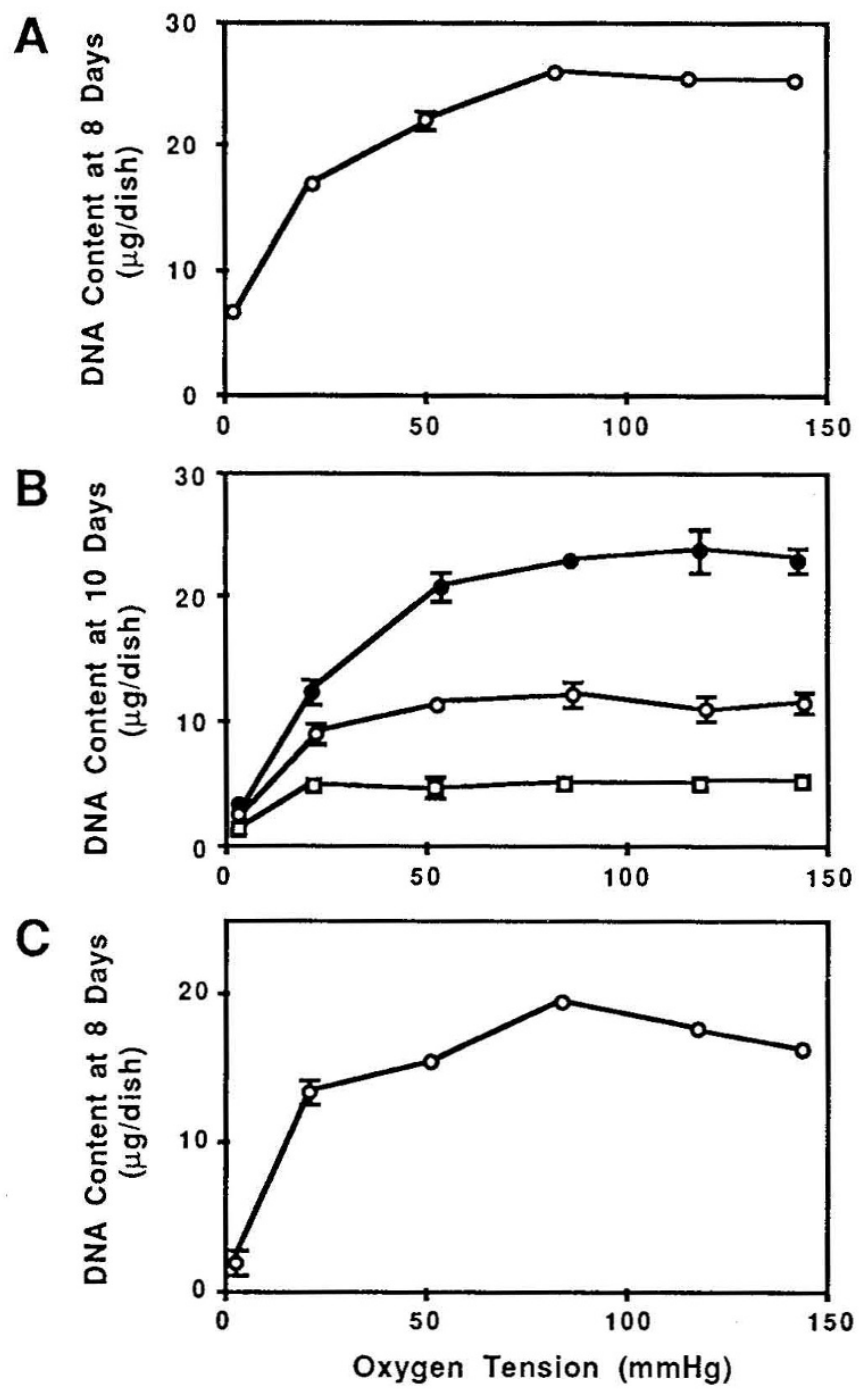

Fig. 6. Effects of altered culture conditions. $A$, fetal pulmonary arterial SMC were plated at $20 \times 10^{3}$ (rather than $\left.2.5 \times 10^{3}\right) \mathrm{cells} / \mathrm{cm}^{2}$ in DMEM with $10 \%$ FBS. Proliferation was reduced at oxygen tensions below $60 \mathrm{~mm} \mathrm{Hg}(p<0.0005) . B$, fetal pulmonary arterial SMC were plated as in Figure 1, but in DMEM with $5 \%(\square), 10 \%(O)$, or $20 \%(\bullet)$ FBS. Reducing the concentration of serum decreased the rate of cell proliferation, limiting the maximum cell density achieved at any oxygen tension, and reduced the threshhold oxygen tension below which reduced proliferation became apparent. Growth was not altered by variation in oxygen tensions between 80 and $150 \mathrm{~mm} \mathrm{Hg}$ in any of these media, but was reduced at low oxygen tensions in all three $(p<0.0005) . C$, fetal pulmonary arterial SMC were plated as in Figure 1, but in equal parts DMEM and F12 media supplemented with $20 \%$ FBS. Growth was modestly but significantly $(p<0.0005)$ reduced at oxygen tensions greater than $100 \mathrm{~mm} \mathrm{Hg}$, as well as at oxygen tensions below $50 \mathrm{~mm} \mathrm{Hg}$ $(p<0.0005)$, as compared to controls $(83 \mathrm{~mm} \mathrm{Hg})$.

media of pulmonary arteries of near-term bovine fetuses. These studies demonstrate that low ambient oxygen tensions induce neither hyperplasia nor hypertrophy of fetal pulmonary arterial SMC in culture and that proliferation of these cells is, in fact, reduced as the oxygen tension falls below $50 \mathrm{~mm} \mathrm{Hg}$.

Origin and Phenotype of Cultured SMC. The phenotypic characteristics of cultured SMC are dependent on the methods used for isolation of these cells, the culture conditions, and the period for which the cells are maintained in vitro $(16,29,30)$. SMC obtained from arterial tissue by enzymatic dissociation have the biochemical characteristics of "mature" smooth muscle cells (31-33), exhibit the morphologic features of the "contractile" phenotype, contract in response to angiotensin II, and do not migrate, synthesize DNA, or proliferate (30). After several days in culture, these cells acquire the ultrastructural features of the "synthetic" phenotype, markedly reduce their synthesis of smooth muscle specific $\alpha$-isoactin, begin to incorporate ${ }^{3} \mathrm{H}$ thymidine into DNA, and initiate logarithmic growth (30-33). When these cells are growth-arrested, either by serum deprivation or in postconfluent cultures, synthesis of smooth muscle specific $\alpha$-isoactin recovers, indicating that cultured smooth muscle cells retain their capacity for cytodifferentiation (33).

The explant method for culture of vascular smooth muscle (14) selects those smooth muscle cells in the arterial media that are capable of migrating out of the explant and proliferating immediately (34). Outgrowth of cells from explanted fetal tissues is more rapid than is typical of adult arterial explants (Benitz WE, Bernfield $M$, unpublished observations), possibly because of the greater abundance of "immature" cells in fetal arteries $(35-37)$. We assume, therefore, that the cells obtained from fetal arterial wall explants are primarily representative of the population of "immature" or "undifferentiated" cells (34). SMC cultured by the explant method (14) exhibit the characteristics of the "synthetic" phenotype (16), which corresponds closely to that of "immature" or "undifferentiated" SMC in situ (35). Thus, it seems reasonable to use these cells for studies of arterial growth, development, and remodeling in the fetus and newborn.

Effects of Oxygen Tension on SMC Growth. Culture of mammalian cells at reduced oxygen tensions has been reported to have variable effects on their proliferation, depending on the type of cell studied (38-42). In a few instances, these in vitro effects can be correlated with the in vivo behaviors of the cells. The more rapid proliferation of fibroblasts in hypoxic regions of tissue during wound healing (43) may be reflected in the more rapid growth of these cells at oxygen tensions of 20 to $40 \mathrm{~mm}$ $\mathrm{Hg}$ in vitro $(10,11)$. Chondrocytes proliferate more rapidly in the relatively avascular core of the developing limb bud (44) and in avascular growing mature cartilage, as well as at lower oxygen tensions in vitro (12). Cardiac enlargement in hypoxic fetuses (45) may result, at least in part, from more rapid proliferation of embryonic myocardial cells at decreased oxygen tensions (13). In contrast, although hypoxia leads to increased quantities of smooth muscle in the pulmonary arteries in vivo (1-7), the current results show that low oxygen tensions inhibit proliferation of pulmonary arterial smooth muscle cells in vitro. Moreover, hypertrophy of these cells was not observed under hypoxic conditions.

Significance in Pulmonary Arterial Growth and Remodeling: Origin of new SMC in pulmonary arterial remodeling. The origin of the SMC that form the pulmonary arterial media during normal development has not been specifically studied. It is widely accepted, however, that developing systemic arteries acquire their smooth muscle investment from the surrounding mesenchyme early in embryogenesis and that smooth muscle hyperplasia is responsible for the increasing muscularity of these vessels during subsequent development in the fetus $(35,36)$ and young animal (35-37, 46-50). The pulmonary artery likely acquires its muscular investment by similar mechanisms.

Extension of the smooth muscle investment into peripheral, normally nonmuscular arteries and medial thickening of the muscular pulmonary arteries are rather stereotypic responses to a variety of pulmonary arterial injuries (51), but the origin of the new smooth muscle cells in injured pulmonary arteries has not been extensively studied. Studies of hypoxia-induced pulmonary arterial remodeling suggest that the new SMC in peripheral pulmonary arteries are derived from pericytes and intermediate cells (52-54). Recent reports suggest that pericytes are biochemically and functionally differentiated cells that are distinct from SMC (55-59). The new SMC in the small pulmonary arteries of hypoxic animals may be derived from intermediate cells and those in larger pulmonary arteries may be derived from smooth muscle cells already in the arterial media. 
Proliferating SMC at sites of wound repair or in atheromata acquire the ultrastructural (16) and biochemical (50) characteristics of the "undifferentiated" or "immature" SMC of developing arteries. Thus, even adult vascular smooth muscle cells retain the capacity to modulate their phenotype between the "mature" or "differentiated" and "immature" or "undifferentiated" states (34). The cells that respond to injury in mature arteries therefore may be the same ones that are responsible for development of the muscular investment in immature arteries.

Oxygen tensions in the pulmonary arterial wall in vivo: The minimum extracellular oxygen tension in the wall of the adult rabbit aorta is approximately $22 \mathrm{~mm} \mathrm{Hg}$, with corresponding intraluminal and subendothelial oxygen tensions of 70 and 37 $\mathrm{mm} \mathrm{Hg}$, respectively (60). The oxygen tension in the wall of the fetal pulmonary artery is unknown, but extrapolation from intraluminal oxygen tensions of $16-18 \mathrm{~mm} \mathrm{Hg}(61)$ suggests a minimum $\mathrm{PO}_{2}$ in the range of $6-8 \mathrm{~mm} \mathrm{Hg}$ and a subendothelial $\mathrm{PO}_{2}$ of $8-10 \mathrm{~mm} \mathrm{Hg}$. Postnatally, the oxygen tension in the pulmonary artery lumen is $40-45 \mathrm{~mm} \mathrm{Hg}$, suggesting a minimal intramural $\mathrm{PO}_{2}$ of $12-15 \mathrm{~mm} \mathrm{Hg}$ and a subendothelial $\mathrm{PO}_{2}$ of 20-25 mm Hg. Thus, the current experiments have been performed at oxygen tensions approximating those which might exist in vivo.

\section{CONCLUSIONS}

Although different experimental conditions, perhaps more closely analogous to those found in vivo, might allow hypoxia to promote smooth muscle hyperplasia, reduced proliferation of these cells was consistently observed with reduction in ambient oxygen tension under a variety of conditions. This was true whether the cells were initially contiguous (as they are in situ) or plated at low density. These results suggest that direct effects of hypoxia on proliferation of smooth muscle precursors are not sufficient to account for 1) extension of the smooth muscle investment of the pulmonary arteries during intrauterine development, 2) the postnatal relative regression of muscularity of the pulmonary arteries (following delivery from the relatively hypoxic intrauterine environment), or 3 ) the increased mass of smooth muscle in the pulmonary arteries of hypoxic young animals and infants.

This conclusion implies that these phenomena are mediated by other factors. Hypoxia induces pulmonary arterial constriction, resulting in increased pulmonary arterial pressure and decreased pulmonary blood flow (62); these hemodynamic changes may be required stimuli for structural remodeling, as appears to be the case in mature rats (63). Endocrine responses to hypoxia also may be important; catecholamines, for example, promote SMC proliferation in vitro (64). Pulmonary arterial endothelium responds to changes in the ambient oxygen tension (65-67) and produces factors that promote and inhibit SMC proliferation (68). Hypoxia could alter production or release of these mediators, and may thereby be a necessary (but indirect) stimulus for smooth muscle growth. The increased quantity of smooth muscle in pulmonary arteries following chronic hypoxia could result exclusively from hypoxia-induced differentiation of SMC precursors (such as pericytes [52]) that are distinct from the SMC used in our experiments, or the behavior of these cells in vitro may not accurately reflect their behavior in situ. The data do not address these hypotheses.

These observations suggest another mechanism by which pathologic hypoxia might affect proliferation of pulmonary arterial smooth muscle cells in vivo. If the integrity of the arterial endothelium is disrupted by hypoxic-ischemic (69), endotoxininduced (70), or other injury, the steep transendothelial oxygen gradient (60) may be greatly reduced or eliminated. If intraluminal arterial oxygen tensions return to or remain normal after the injury has occurred, the SMC of the media would be exposed to oxygen tensions of $40-45 \mathrm{~mm} \mathrm{Hg}(16-18 \mathrm{~mm} \mathrm{Hg}$ in utero), which are substantially higher than normal intramural oxygen tensions of $15-25 \mathrm{~mm} \mathrm{Hg}(6-10 \mathrm{~mm} \mathrm{Hg}$ in utero). Our studies suggest that these SMC would then proliferate more rapidly, even if the availability of other substrates and mitogens was not altered either by the stimulus itself or by the endothelial injury. Although potentially operating under pathologic conditions, this mechanism would not account for the changes in pulmonary arterial muscularity that characterize normal development of these vessels.

Acknowledgment. Acetylated low-density lipoprotein was provided by Dr. Robert Auerbach, University of Wisconsin.

\section{REFERENCES}

1. Haworth SG, Hislop AA 1982 Effect of hypoxia on adaptation of the pulmonary circulation to extra-uterine life in the pig. Cardiovasc Res 16:293-303

2. Meyrick B, Reid L 1981 The effect of chronic hypoxia on pulmonary arteries in young rats. Exp Lung Res 2:257-271

3. Meyrick B, Reid L 1982 Normal postnatal development of the media of the rat hilar pulmonary artery and its remodeling by chronic hypoxia. Lab Invest 46:505-514

4. Rabinovitch M, Gamble W, Miettinen OS, Reid L 1981 Age and sex influence on pulmonary hypertension of chronic hypoxia and recovery. Am J Physiol 240:H62-H72

5. Naeye RL, Letts HW 1962 The effect of prolonged neonatal hypoxemia on the pulmonary vascular bed and heart. Pediatrics 30:902-908

6. Kendeel SR, Ferris JAJ 1977 Apparent hypoxic changes in pulmonary arterioles and small arteries in infancy. J Clin Pathol 30:481-485

7. Meyrick B, Reid L 1980 Ultrastructural findings in lung biopsy material from children with congenital heart defects. Am J Pathol 101:527-537

8. Kaufman OY 1964 Intrauterine development of pulmonary vessels in man. Arkh Anat Gistol Embryol 46:T584-T588

9. Levin DL, Rudolph AM, Heymann MA, Phibbs RH 1976 Morphological development of the pulmonary vascular bed in fetal lambs. Circulation 53:144-151

10. Balin AK, Goodman DB, Rasmussen H, Cristofalo VJ 1976 The effect of oxygen tension on the growth and metabolism of WI- 38 cells. J Cell Physiol 89:235-249

11. Tanswell AK, Smith BT 1980 Influence of oxygen tension and cortisol environment upon growth and cortisone conversion to cortisol by cultured human fetal fibroblasts. Biol Neonate 37:32-38

12. Dehnel JM, Hamblen DL 1977 Influence of oxygen tension on somatomedin activity in vitro. J Endocrinol 72:361-369

13. Hollenberg M 1971 Effect of oxygen on growth of cultured myocardial cells. Circ Res 28:148-157

14. Ross R 1971 The smooth muscle cell II; growth of smooth muscle in culture and formation of elastic fibers. J Cell Biol 50:172-186

15. Benitz WE, Coulson JD, Lessler DS, Bernfield M 1986 Heparin inhibits proliferation of fetal vascular smooth muscle cells in the absence of plateletderived growth factor. J Cell Physiol 127:1-7

16. Chamley-Campbell J, Campbell GR, Ross R 1979 The smooth muscle cell in culture. Physiol Rev 59:1-61

17. Gimbrone MA, Cotran RS 1975 Human vascular smooth muscle in culture: growth and ultrastructure. Lab Invest 33:16-27

18. Lewis LJ, Hoak JC, Maca RD, Fry GL 1973 Replication of human endothelial cells in culture. Science 181:453-454

19. Schwartz SM 1978 Selection and characterization of bovine aortic endothelial cells. In Vitro 14:966-980

20. Striker GE, Harlan JM, Schwartz SM 1980 Human endothelial cells in vitro. Methods Cell Biol 21A:135-151

21. Voyta JC, Via DP, Butterfield CE, Zetter BR 1984 Identification and isolation of endothelial cells based on their increased uptake of acetylated-low density lipoprotein. J Cell Biol 99:2034-2040

22. Adams RLP 1980 Cell Culture for Biochemists. In: Laboratory Techniques in Biochemistry and Molecular Biology, Vol. 8. Elsevier-North Holland, Amsterdam, pp 73-75

23. Labarca C, Paigen K 1980 A simple, rapid and sensitive DNA assay procedure. Anal Biochem 102:344-352

24. Bearden JC 1978 Quantitation of submicrogram quantities of protein by an improved protein-dye binding assay. Biochem Biophys Acta 533:525-529

25. Glantz SA 1981 A Primer of Biostatistics. McGraw-Hill, New York

26. Bierman EL, Albers JJ 1976 Lipoprotein uptake and degradation by human arterial smooth muscle cells in tissue culture. Ann NY Acad Sci 275:199203

27. Kuehl KS, Bruttig SP, Singer DV, Rubio R, Berne RM 1981 Growth of aortic vascular smooth muscle cells in lowered oxygen tension. Cell Tissue Res 216:591-602

28. Kuehl KS, Holloway PW 1983 Lipoprotein uptake by vascular smooth muscle cells of the rat cultured in 5\% or $20 \%$ oxygen. Cell Tissue Res $233: 453-462$

29. Chamley-Campbell JH, Campbell GR, Ross R 1981 Phenotype-dependent response of cultured aortic smooth muscle to serum mitogens. J Cell Biol 89:379-383

30. Chamley-Campbell JH, Campbell GR 1981 What controls smooth muscle phenotype? Atherosclerosis 40:347-357 
31. Fatigati V, Murphy RA 1984 Actin and tropomyosin variants in smooth muscles. J Biol Chem 259:14383-14388

32. Palmberg L, Sjolund M, Thyberg J 1985 Phenotype modulation in primary cultures of arterial smooth-muscle cells: reorganization of the cytoskeleton and activation of synthetic activities. Differentiation 29:275-283

33. Owens GK, Loeb A, Gordon D, Thompson MM 1986 Expression of smooth muscle-specific $\alpha$-isoactin in cultures vascular smooth muscle cells: Relationship between growth and cytodifferentiation. J Cell Biol 102:343-352

34. Ross R 1981 Atherosclerosis: a problem of the biology of arterial wall cells and their interactions with blood components. Arteriosclerosis 1:293-311

35. Kolcher O, Skalli O, Cerutti D, Gabbiani F, Gabbiani G 1985 Cytoskeletal features of rat aortic celis during development. Circ Res 56:829-838

36. Campbell GR, Chamley JH 1976 Ultrastructure of differentiating vascular smooth muscle. In: Bevan JA (ed) Vascular Neuroeffector Mechanisms Second International Symposium, Odense, 1975. Karger, Basel, pp 1-9

37. Stein O, Eisenberg S, Stein Y 1969 Aging of aortic smooth muscle cells in rats and rabbits. Lab Invest 21:386-396

38. Wright GP 1928 The oxygen necessary for the mitosis of certain embryonic and neoplastic cells. J Pathol Bacteriol 31:735-752

39. Cooper PD, Wilson JN, Burt AM 1959 The bulk growth of animal cells in continuous suspension culture. J Gen Microbiol 21:702-720

40. Taylor WG, Richter A, Evans VJ, Sanford KK 1974 Influence of oxygen and pH on plating efficiency and colony development of WI-38 and Vera cells. Exp Cell Res 86:152-156

41. Taylor WG, Camalier RF 1982 Modulation of epithelial cell proliferation in culture by dissolved oxygen. J Cell Physiol 111:21-27

42. Pentland AP, Marcelo CL 1983 Modulation of proliferation in epiderma keratinocyte cultures by lowered oxygen tension. Exp Cell Res 145:31-43

43. Niinikoski J 1969 Effect of oxygen supply on wound healing and formation of granuloma tissue. Acta Physiol Scand [Suppl] 334:1-72

44. Caplan AI, Koutroupas S 1973 The control of muscle and cartilage development in the chick limb: The role of differential vascularization. J Embryol Exp Morphol 29:571-583

45. Hollenberg M, Honbo N, Samorodin AJ 1976 Effects of hypoxia on cardiac growth in neonatal rats. Am J Physiol 231:1445-1450

46. Frist S, Stemerman MB 1975 Arterial growth and development. In: Bevan JA (ed) Vascular Neuroeffector Mechanisms Second International Symposium, Odense, 1975. Karger, Basel, pp 19-27

47. Cliff WJ 1967 The aortic tunica media in growing rats studied with the electron microscope. Lab Invest 17:599-615

48. Gerrity RG, Cliff WJ 1975 The aortic tunica media in the developing rat. I. Quantitative stereologic and biochemical analysis. Lab Invest 32:585-600

49. Yurokova Z, Hadjilsky P, Renais J, Scebat L 1976 On the proliferative activity of arterial smooth muscle cells in rat postnatal ontogenesis: auto-historadiographic studies. Atherosclerosis 23:297-304

50. Skalli O, Gabbiani G 1985 Remodeling of the aortic smooth muscle cell cytoskeleton during development and pathological conditions. Pathol Res Pract 180:338-341

51. Reid LM 1979 The pulmonary circulation: remodeling in growth and disease. Am Rev Respir Dis 119:531-546
52. Meyrick B, Reid L 1978 The effect of continued hypoxia on rat pulmonary arterial circulation: an ultrastructural study. Lab Invest 38:188-200

53. Meyrick B, Reid L 1979 Hypoxia and incorporation of ${ }^{3} \mathrm{H}$-thymidine by cells of the rat pulmonary arteries and alveolar wall. Am J Pathol 96:51-70

54. Meyrick B, Fujiwara K, Reid L 1981 Smooth muscle myosin in precursor and mature smooth muscle cells in normal pulmonary arteries and the effect of hypoxia. Exp Lung Res 2:303-313

55. Joyce NC, DeCamilli P, Boyles J 1984 Pericytes, like vascular smooth muscle cells, are immunocytochemically positive for cyclic GMP-dependent protein kinase. Microvasc Res 28:206-219

56. Joyce NC, Haire MF, Palade GE 1985 Contractile proteins in pericytes. I Immunoperoxidase localization of tropomyosin. J Cell Biol 100:1379-1386

57. Joyce NC, Haire MF, Palade GE 1985 Contractile proteins in pericytes. II Immunocytochemical evidence for the presence of two isomyosins in graded concentrations. J Cell Biol 100:1387-1395

58. Herman IM, D'Amore PA 1985 Microvascular pericytes contain muscle and nonmuscle actins. J Cell Biol 101:43-52

59. Sims DE, Westfall JA 1983 Analysis of relationships between pericytes and gas exchange capillaries in neonatal and mature bovine lungs. Microvasc Res 25:333-342

60. Niinikoski J, Heughan C, Hunt TK 1973 Oxygen tensions in the aortic wall of normal rabbits. Atherosclerosis 17:353-359

61. Rudolph AM 1974 Congenital Diseases of the Heart. Year Book Medical Publishers, Chicago, p 4

62. Rabinovitch M, Gamble WJ, Nadas AS, Miettinen OS, Reid L 1979 Rat pulmonary circulation after chronic hypoxia: Hemodynamic and structural features. Am J Physiol 236:H818-827

63. Rabinovitch M, Konstam MA, Gamble WJ, Papanicolaou N, Aronovitz MJ, Treves S, Reid L 1983 Changes in pulmonary blood flow affect vascular response to chronic hypoxia in rats. Circ Res 52:432-441

64. Blaes N, Boissel J-P 1983 Growth-stimulating effect of catecholamines on rat aortic smooth muscle cells in culture. J Cell Physiol 116:167-172

65. Krulewitz AH, Fanburg BL 1984 The effect of oxygentension on the in vitro production and release of angiotensin converting enzyme by bovine pulmonary artery endothelial cells. Am Rev Respir Dis 130:866-869

66. Cummiskey JM, Simon LM, Theodore J, Ryan US, Robin ED 1981 Bioenergetic alterations in cultivated pulmonary artery and aortic endothelial cells exposed to normoxia and hypoxia. Exp Lung Res 2:155-163

67. Krulewitz AH, Fanburg BL 1984 The effect of oxygen tension on the in vitro production and release of angiotension-converting enzyme by bovine pulmonary artery endothelial cells. Am Rev Respir Dis 130:866-869

68. Benitz WE, Kelley RT, Bernfield M 1985 Fetal pulmonary arterial endothelia cells produce inhibitors and promoters of smooth muscle cell proliferation. J Cell Biol 101:107a(abstr)

69. Elemer G, Kerenyi T, Jellinek H 1976 Scanning (SEM) and transmission (TEM) electron-microscopic studies on post-ischemic endothelial lesions following recirculation. Atherosclerosis 24:219-232

70. Reidy MA, Schwartz SM 1983 Endothelial injury and regeneration IV: endotoxin: a nondenuding injury to aortic endothelium. Lab Invest 48:25-34 